\title{
Al-Ghazālī’s Moderation in Belief
}

Alladin M. Yaqub, trans. (with an interpretive essay and notes) Chicago, University of Chicago Press, 2014. 344 pages.

Al-Ghazali (Abu Hamid Muhammad ibn Muhammad al-Tusi al-Ghazali, 1058-1111) is one of the most important thinkers in the history of Islamic and Arabic thought. He lived and wrote at the height of the intellectual ferment of Islam. Originally from Tus (in modern day Iran), he traveled extensively throughout the Muslim world. Al-Ghazali was a leading religious intellectual during his lifetime; he was a jurist (faqīh), a theologian (mutakallim), as well as a Sufi. Three of his most famous works are: The Incoherence of the Philosophers, Deliverer from Error, and Revivification of the Religious Sciences. The first work contains al-Ghazali's famous and devastating attack on philosophy, and while it deals in large measure with theology and theological claims, it is principally a refutative work. In this book, al-Ghazali investigates philosophical doctrines and criticizes philosophers for holding many heretical opinions, especially for three blasphemous views that are deserving of death: the belief in the pre-eternity of the world (in effect denying God's creation of the world), the denial of God's knowledge of particulars, and the denial of the resurrection of bodies and their assembly at the Day of Judgment. This work is largely re- 
sponsible for discrediting philosophy within the wider Islamic community in the Middle Ages. His intellectual or spiritual autobiography, The Deliverer from Error, is nearly as influential. Among other matters, the work traces alGhazali's account of his own descent into skepticism and his emergence therefrom, thanks to God, Who cast a light of certainty into al-Ghazali's heart and delivered him from error. His magnum opus, Revivification of the Religious Sciences, deals comprehensively with religious sciences and helped establish the respectability of mysticism (Sufism) within mainstream Islam.

Aladdin M. Yaqub, a professor of philosophy at Lehigh University, has translated into English another important work by al-Ghazali, Moderation in Belief. This book contains al-Ghazali's most comprehensive exposition of his theological views. It will be of interest to those who work in theology and metaphysics, the history of philosophy, medieval philosophy, and Islamic philosophy. Those interested in the history of political thought, especially medieval or Islamic, could benefit from reading al-Ghazali's reflections on more strictly theological matters in order to see how or to what extent al-Ghazali's theological views relate to his political thought.

This new edition of Moderation in Belief consists of an unabridged translation of al-Ghazali's most sustained work on theology, comprising two prefaces, four introductions, and four treatises. The content reveals the theological focus of the work. In the first treatise, al-Ghazali presents his reflections on the essence of God; in the second, the attributes of God; and in the third, the acts of God. In the final treatise, al-Ghazali turns to matters more distinctly Islamic: he defends the prophethood of Muhammad, revelation, and the Imamate, concluding the work with an account of those who should be charged with unbelief. In addition to his translation of al-Ghazali's text, Yaqub has added a note explaining his principles of translation, a brief introduction, and an extended interpretive essay at the end of the text. There are also a bibliography, and helpful indices for Quranic verses, Hadiths, and subjects covered in the text.

As the first complete English translation of the work, Yaqub's book represents a significant contribution for the non-Arabic speaker. Arabic speaking audiences will also benefit from Yaqub's scholarly documentation of the text in the footnotes. Yaqub is largely successful in bridging the unavoidable gap in translation between a faithful rendering of the original and readability. Perhaps the most important task in translating scholarly treatises, especially those by deliberate and precise authors such as al-Ghazali, is consistency in rendering the work's key technical terms. Unconventional or debatable renderings of terms are acceptable as long as the translator justifies the choice and explains its logic. Yaqub follows this convention with some success. For exam- 
ple, at certain points in the translation, he renders the well-known term ilm (alternatively translated as knowledge, science, and a known thing) as "cognition." Cognition and derivatives such as cognizance are usually terms that scholars of Arabic reserve for 'ilm's synonym ma 'rifah. Yaqub flags his translation in a footnote, explaining why a departure from convention is justified in this case. His abundant footnotes keep the reader alert to the fine points of the translation and provide useful historical background and explanation for obscure logical formula. The non-translation related material can be distracting at times and would have been better left to endnotes. Yaqub also occasionally misses the opportunity to guide the reader in other key passages in al-Ghazali's discussion. For example, an explanation of the logic behind the translation of key terms such as fikr (thought), talab (seeking), nazar (theoretical reflection), and tafattun (understanding) would be helpful to the reader (pp. 17-18).

One shortfall of the translation is worth noting. It is clear from the language and style of the text that al-Ghazali wrote the book for a middling reader, who is neither an expert in theology or philosophy nor a complete novice. Yaqub acknowledges as much in a footnote to the text (pp. 15-16, n. 35). An ideal translation would thus be consistent with the spirit of al-Ghazali's objective. Although Yaqub's translation is largely accessible, at key passages in the book, he abandons accessibility for complex and (perhaps unnecessary) translation choices, such as translating qadim (old, ancient, or prior) as "anterior eternity" and baqa' (remaining or abiding) as "posteriorly eternal." While he presents an argument for his renderings, the choices distort al-Ghazali's intention for accessibility. The non-specialist reader might struggle to understand what it means that God is prior (qadim) or abiding (baqa'), but he or she will likely find these terms more accessible than "anterior eternity" and "posteriorly eternal."

Yaqub's interpretive essay is extremely helpful, especially for one not well acquainted with al-Ghazali's thought or with Islamic theology generally. The interpretive essay presents a straightforward summary or epitome of the work, adumbrating the major points of each treatise of al-Ghazali's book and drawing out their implications in clearly divided sections. The reader can thus alternate between the text and the interpretive essay easily. In addition to introducing and explaining al-Ghazali's thought, Yaqub provides the reader with the requisite background knowledge, situates al-Ghazali's thought within the dominant theological disputes of his day, and relates how al-Ghazali's thought explicates an aspect of Asharite theology. Yaqub also presents the theological positions of those against whom al-Ghazali argues, including the Mutazalites, the Maturidites, and the philosophers. 
Given his enormous influence on Islamic thought, this new translation of al-Ghazali's Moderation in Belief is indispensable for one who seeks to understand his theology. This book will be of great service to scholars, both Arabic and non-Arabic speakers, and it could also be assigned in upper level undergraduate courses as well as graduate seminars. Given, however, that al-Ghazali's book was written for the middling reader, and that al-Ghazali divides ideas into three parts - those held in common with the masses, those exhorting all who seek the truth, and those a man keeps to himself and divulges only to people who share his beliefs - given these matters, one would have to read his corpus more broadly in order to situate Moderation in Belief within al-Ghazali's thought and arrive at a definitive understanding of his theology. Yaqub's new translation no doubt aids in that endeavor and is thus warmly welcomed.

Gregory A. McBrayer Assistant Professor of Government Morehead State University, Morehead, KY

Waseem El-Rayes Associate Professor, James Madison College Michigan State University, East Lansing, MI 